\title{
Exploring the Effects of Recursive Conversations on L2 Learner Beliefs
}

\section{David. S. Bowyer \\ Nagoya Gakuin University}

\section{Reference Data:}

Bowyer, D. S. (2019). Exploring the effects of recursive conversations on L2 learner beliefs. In P. Clements, A. Krause, \& P. Bennett (Eds.), Diversity and inclusion. Tokyo: JALT.

Recursion, developed from sociocultural perspectives on language learning, has been described by Kindt (2004) as the "return to a similar experience-but with wider knowledge" (p. 15). By engaging in recursive conversations, learners can iterate on their $L 2$ oral interactions through the use of interaction-focused feedback and conversations with multiple partners. This study builds on preliminary research by Murphey (2003) and Kindt and Bowyer (2018) that explored the effects of recursion on learners' L2 competence and beliefs but were too broad in scope and worked with limited data. This present case study employed a mixed methods approach in which interviews and surveys were conducted with 48 first-year English learners at a Japanese university, with the aim of examining the effects of recursive conversations on language learning beliefs. Results indicated belief changes in the areas of (a) peer interaction, (b) L2 oral competence, and (c) selfefficacy. However, further research is required.

反復とは、言語学習における社会文化理論の観点において発展した、「より幅広い知識を持ち、類似した経験に戻ること」で あると定義されている(Kindt，2004，p. 15)。反復会話活動を通して、学習者は第二言語を用いて多様なパートナーとの活動と フィードバックを受ける機会を得ることができる。本研究は、反復活動の学習者の第二言語習得度及び学習者の言語学習に おける考えに対しての効果について焦点が置かれたMurphey (2003) とKindt \& Bowyer (2018)の研究に基づいて行われた。 本事例研究では 反復会話活動の学習者の言語学習に関する考えに対しての効果について調查するために、日本の大学に在 籍する1年生48名を対象としてインタビューとアンケートを用いての混合研究法が䒠施された。結果として学習者の考えは

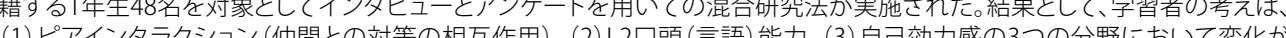
示された。いしながらっり明確な結論を䆃き出す前にささらなる研究調查の実施が必要とされるだろう。 s sociocultural theory (SCT) has gained acceptance as a useful tool for examining I second language acquisition, it has had wide-ranging effects on second language teaching and research. Interactional competence theory, with its holistic focus on communication as a shared experience, demands that educators find innovative ways of scaffolding learners' interactions in order to hasten L2 progression (Brown, 2014, p. 216). Recursive conversations (RCs) have shown promise as a tool for aiding learners in becoming more proficient oral interactors (Kindt \& Bowyer, 2018).

This mixed methods case study was aimed at building on the preliminary research results described by Kindt and Bowyer (2018) by exploring the effects of RCs on learners' beliefs. An exploratory technique (Creswell, Plano Clark, Gutman, \& Hanson, 2003), to obtain qualitative data from four interviews and quantitative data from two surveys, was employed with a group of 48 learners during their first semester at a Japanese university. The results are followed by a discussion of the implications of RCs for learners and educators. The paper concludes with a summary of the key issues and further research areas

\section{Literature Review}

\section{Interactional Competence}

Since Canale and Swain's (1980) introduction of communication strategies (CSs) as a tool for language learners during L2 oral interaction, the definition of what constitutes CSs has continually developed. From the initial vision of CSs as a way to repair communication breakdowns, many researchers have moved towards an expanded definition encompassing all aspects of oral interaction, while taking into account the importance of cross-cultural issues (Brown, 2014). In this expanded definition, Young (2011) identified three broad areas of competence: (a) identity resources, (b) linguistic resources, and (c) interactional resources. These can be broken down into seven further components: (a) participation framework, (b) register, (c) selection of forms in modes 
of meaning, (d) speech acts, (e) turn-taking, (f) repair, and (g) boundaries. According to Young, "command of language forms is not enough to ensure successful communication" (p. 426). Learners must be provided with not only the language necessary for interaction, but also experiences of using CSs to successfully navigate L2 oral interaction.

\section{Recursive Conversations}

Recursion is a process in $\mathrm{L} 2$ learning that promotes the developmental restructuring of one's interlinguistic system through the "return to a similar experience-but with a wider knowledge" (Kindt, 2004, p. 15). As O'Connor and McDermott (1997) suggested, it can be viewed as "a spiral staircase to bring you to higher and higher levels" (pp. 100-101). Recursion typically involves "listening to/watching language production, doing followup activities, focusing on forms, self-evaluating, receiving peer evaluation. .. within slightly different contexts" (Kindt, 2005, p. 176). By revisiting L2 experiences, learners can "reveal, construct, restructure, and scaffold understandings" in order to achieve increased competence (Murphey, 2001, p. 143). Recursion is influenced by SCT, in that the recursive process is presumed to aid learners by increasing their zone of proximal development, leading to improved learning outcomes in areas such as learner autonomy and metacognitive awareness (Murphey, 2001).

In a 2003 study, Murphey found that multiple conversations with peers led to increased confidence and feelings of L2 ownership, indicating that RCs may impact positively on learners' language competence and beliefs. More recently, Kindt and Bowyer's (2018) research showed that learners considered RCs to be more interesting and less challenging in comparison to single conversations. These studies provide tentative evidence for the belief changes that can be brought about through the use of RCs, which include multiple conversations about the same topic interlaced with interaction-focused tutor feedback (see Appendix A).

\section{Learner Beliefs}

The nature of learner beliefs and their relationship with $\mathrm{L} 2$ acquisition has been an area of intense research in the TESOL community. Early research tended to view beliefs as being "preconceived notions. . . or misconceptions" that affect how learners interact with the L2, usually known as the normative approach (Ellis, 2008). However, recent research has mostly rejected this in favor of more interactive contextual models "with a dynamic/ complexity orientation" (Weseley, 2012, p. 110). In these models, the complex interplay between learner and environment shapes - and is shaped by - the learner's beliefs about language learning, making learning experiences a key $\operatorname{cog}$ in belief formation and change (Barcelos, 2006). Nguyen and Sato (2016) examined the effect of group and pair work on L2 English learners' beliefs and found that self-efficacy improved significantly over the 7-week study, with perceptions of peer learning also improving. This emphasizes the dynamic and complex nature of learner beliefs and the notion that beliefs can change dramatically in a relatively short period of time. Based on the research of Murphey (2003), Nguyen and Sato (2016), and Kindt and Bowyer (2018), three research questions were devised for the current study to more deeply explore RCs' effects on learners' beliefs.

\section{Research Questions}

RQ1. How do learners perceive their peers during RCs?

RQ2. Do learners believe that RCs help them to increase their $\mathrm{L} 2$ oral competence? RQ3. Do RCs lead to increased feelings of self-efficacy?

\section{Method}

\section{Participants}

The study was conducted with 48 first-year English education majors at a Japanese university, divided into two oral communication classes of equal size. These classes were taught by eight native speakers of English, including the author of this paper, for 45 minutes each week during the first semester. Four learners were selected for interviews based on their performance in a rubric-assessed group conversation (Appendix C) in the first class. Selection of these learners was based on Dörnyei's (2007) recommendation that purposeful sampling should "provide rich and varied samples" (p. 216), with the learners representing the breadth of $\mathrm{L} 2$ levels in the class. The selected learners were classified as female-low (Saori), female-high (Ayana), male-low (Riki), and male-high (Ryuichi), based on their performance scores. To protect anonymity, pseudonyms are used.

\section{Procedure}

The class was set up in the same way each week, with learners divided into preassigned groups of three, each with its own tutor. Classes began with a 10-minute CS practice activity (Appendix A; Appendix B), such as asking follow-up questions, referred to in class as "conversation skills" (Amrein et al., 2017). This activity was followed by three

7-minute, three-person RCs, with tutors providing informal feedback after Conversation 
1, and rubric-based feedback between Conversation 2 and Conversation 3(Appendix C). During these conversations, learners were allowed to use L2 conversation notes that they had prepared before coming to class, known as Let's Talk (Appendix B).

This case study was conducted based on mixed methods research principles, employing qualitative interviews and quantitative surveys. As RCs are not currently well understood, an exploratory research design based on Creswell et al. (2003) was used, in order to explore RCs effects on learner beliefs (p. 220). Qualitative interviews were conducted to clarify areas of inquiry, which were tested and expanded upon using surveys. Four semiopen interviews (Appendix D) were conducted between the author and the selected learners in Japanese, all questions having been piloted with a professional peer. Written questions were used as beginning points for areas of interest, which were expanded upon ad hoc. Recordings were transcribed and coded for themes, then reviewed by a peer. Typically, six or more interviewees would be considered a good number (Dörnyei, 2007). However, the exploratory nature of this research meant that interviews were mainly important for their use in creating themes for the surveys rather than creating a thick description of learner experiences, making a smaller number appropriate.

The codes were developed into two closed-item surveys, then translated into Japanese by a native speaker (Appendix E). Survey items were piloted with a professional peer, then with a student who had prior experience of a similar course. The surveys were administered at the middle and end of the first semester and were completed by all available learners, including the four interviewees. However, because of the loss of two learners from the course, several absences, and some skipped questions, response rates were around $80 \%$. The interview and survey data were compared and contrasted in a final mixing stage. Due to the nonrandom sample, inferential statistics were not used.

\section{Results}

As the survey questions were created in order to test and expand upon the interviews, the results of both are presented together sequentially. All numerical data are presented in graphical form, with tabulated summaries available in Appendix F.

\section{RQ1: Learner Perceptions of Their Peers in RCs}

When asked about their thoughts on the act of engaging in L2 RCs with their peers, the interviewees responded with positive phrases signifying that they believed talking with peers to be beneficial to their language development. For example, Ayana stated,
でも相手がそういうこと言うとあ一ってなるうふふああって思い出して言わな一ってなります [but if a partner says that thing then I think ah haha ah I remember and I remember to say it]

Ayana seems to be implying that she believes that she becomes able to use spoken L2 forms that she previously could not through copying her peers. In order to find out if this was a widespread belief, several questions were added to the surveys. The results are shown in Figure 1.

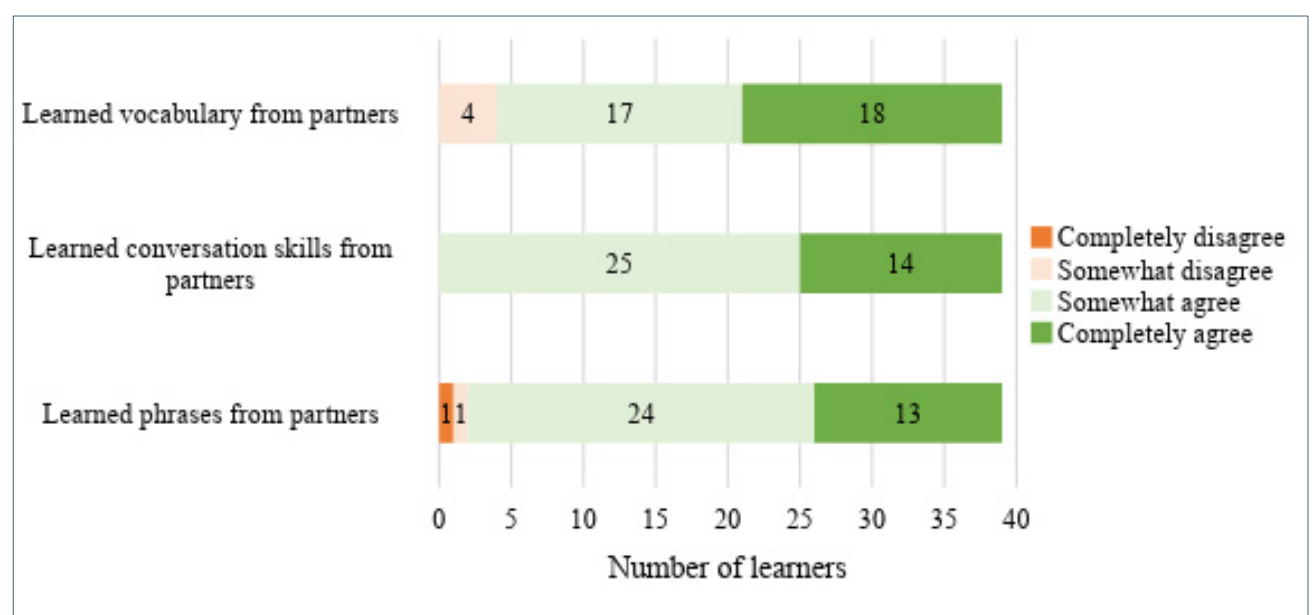

Figure 1. Learner beliefs regarding learning from their peers in RCs (Survey 2, Q. 1-3). Summary data in Appendix F.

As Figure 1 clearly shows, the majority of the group held similar beliefs to those of Ayana regarding their peers in RCs. Thirty-five of 39 respondents displayed the belief that they learned new vocabulary from their partners during RCs. Thirty-seven learners shared Ayana's belief that they learned new phrases from their partners through their experiences in RCs. Furthermore, all respondents agreed that they had learned conversation skills from their peers.

RQ2: Learner Beliefs Regarding Their Competence in RCs

During the interviews, learners were asked if they had noticed any changes in their approach to conversations as they moved through the RCs. As exemplified by Saori, they 
reported noticing an improvement in the quality of their conversations:

ま三番目の方が一番頑張れるし出来るようにはなっているつもりなんですけど [l think can try harder and do better in the third conversation]

Saori stated that she felt she was able to put forth more effort in the third conversation and to perform to an unspecified higher level. Similar feelings were displayed by the other interviewees, which indicated that, regardless of any actual changes in performance, the learners felt that RCs aided them in making rapid iterations to their L2 oral performance. Several questions based on this were added to the surveys. The results are shown in Figure 2.

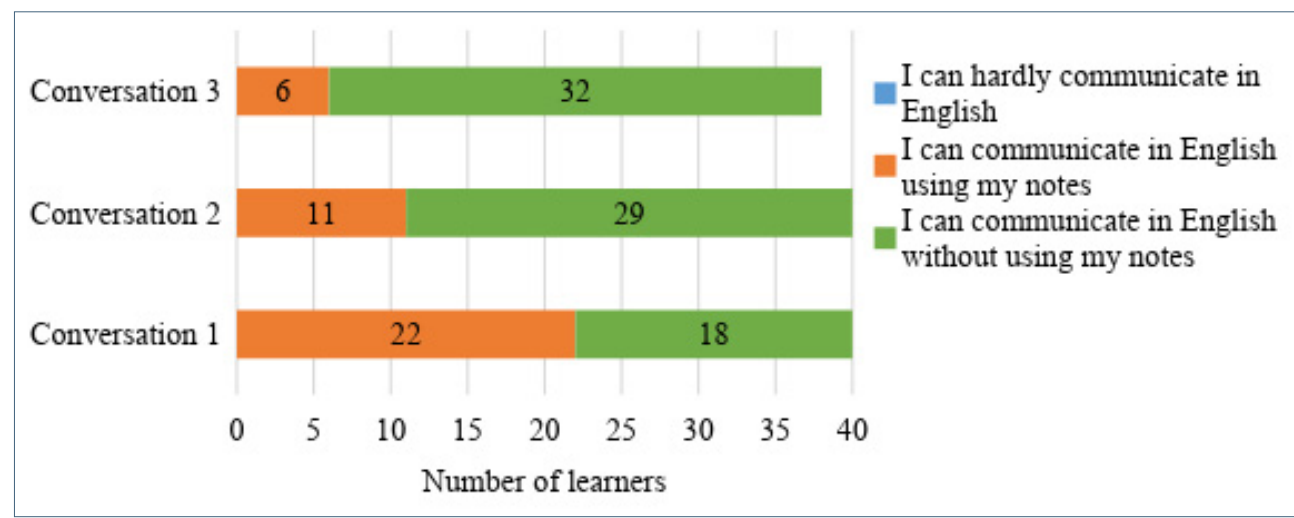

Figure 2. Learner beliefs regarding their performance during RCs (Survey 1, Q. 38-40). Summary data in Appendix F.

As can be seen in Figure 2, responses show that learners perceived improvements in their performance when moving through the RCs. Eighteen of 40 respondents reported feeling that they were generally capable of communicating in the L2 without using their prepared notes in Conversation 1. This increased to 29 for Conversation 2, then again to 32 of 38 for Conversation 3. Of the 22 learners who required notes for Conversation 1 , at least 14 felt that they no longer required that form of scaffolding by the third conversation. This is emphasized by the movement of the median score from I can communicate in English using my notes in Conversation 1, to I can communicate in English without using any notes in Conversations 2 and 3.
RQ3: Learner Beliefs Regarding RCs Effects on L2 Oral Self-Efficacy A common thread throughout the interviews was the perceived effect of RCs on oral competence, with interviewees indicating a general feeling that their competence increased through RCs, as exemplified by Riki and Ryuichi:

Riki: なんかより英語力つていうのが身につくと思います [1 think my English ability increases even more]

Ryuichi: And I can get uh try to use new phrases or reactions ... I become to use uh new phrases on the textbook ... by the way... or ah anyway

Riki stated that he believed RCs to be beneficial for his L2 development, but did not provide further details regarding the types of changes that he believed to be occurring. Ryuichi's comment sheds more light on the issue, as he stated that the RCs have aided him in the use of new phrases and reactions, mentioning two phrases that were taught in the class. These issues were expanded upon in the surveys. The results are shown in Figure 3.

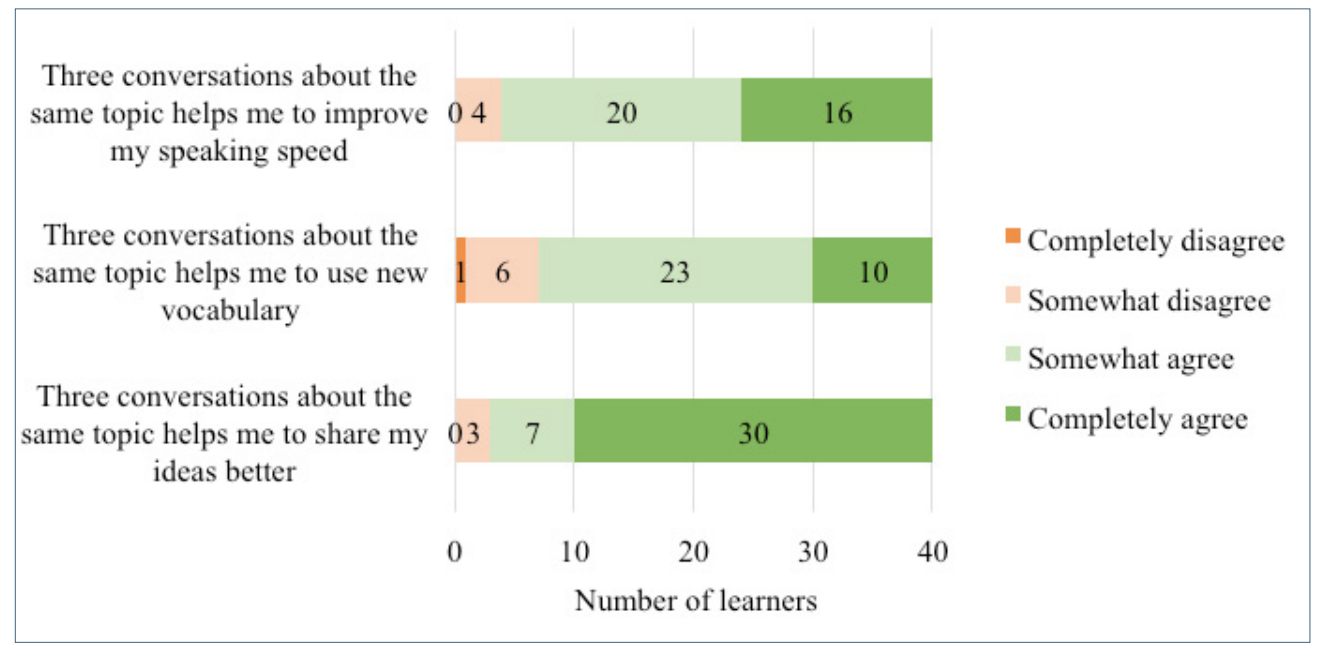

Figure 3. Learner beliefs regarding RCs and oral competence (Survey 1, Q. 43,48,51). Summary data in Appendix F. 
When asked about their perceptions of the effects of RCs on oral fluency, 36 of 40 respondents agreed that their speaking speed was improving, but four did not, with somewhat agree being the median score. Broadly the same results can be seen for new vocabulary usage. The third question returned the strongest results, with 37 of 40 respondents indicating that they believed RCs aided them in improving their ability to share their ideas: completely agree represented the median score.

\section{Discussion}

Through the course of conducting the interviews, three main codes became apparent. When explored through the surveys, these codes led to three key themes in the areas of (a) peer interaction, (b) L2 oral competence, and (c) self-efficacy. In each of these areas, RCs appear to have had an effect on the learners' beliefs. The implications of these codes for the three stated research questions are now discussed.

How Do Learners Perceive Themselves and Their Peers During RCs? One of the most interesting developments to come out of the interviews was that learners believed that they were able to utilize RCs as a peer learning tool. This belief was shown to be true for almost the entire group: at least $90 \%$ of the 39 survey respondents reported that they had learned all three of (a) new English vocabulary, (b) new phrases, and (c) new communication skills from their partners during RCs (see Figure 1). The belief that an $\mathrm{L} 2$ can only be learned from native speakers has been shown to be common in Japan (Sato, 2005). The fact that such a large proportion of the survey group reported the belief that they had learned new L2 from their peers during RCs implies that RCs themselves were the primary driver of the acquisition of these beliefs.

In a broader context, this may suggest that RCs may be a useful tool in learning situations where learner autonomy and peer interaction are seen as desirable, as RCs can help learners to perceive the potential positives that can be derived from this kind of environment. Because RCs allow learners to perceive the benefits of learning from their fellow nonnative peers, they may play an important role in learning situations in which the availability of native speakers is limited, such as the Japanese public school system.

\section{Do Learners Believe That RCs Help Them to Increase Their L2 Oral} Competence?

It became clear in the interviews that the interviewees had noticed changes in their ability to speak in the $\mathrm{L} 2$ during the RCs in each class, with the third conversation being singled out as the one in which they felt that they had performed to the highest level. This was borne out in the survey results, which showed that many learners in the group found that they came to no longer rely on their prepared notes during the second and third conversations.

On an intuitive level, the perceived performance increase makes sense; a golfer experiencing a course for the third time will likely do better than they did on their first try. From a sociocultural perspective, it appears to be the case that the RCs act as a form of oral scaffolding for the learners (Oliver \& Philp, 2014). In the first conversation, learners are beginning to become familiar with the language forms and interactional skills required, and they are activating the relevant schema (Stubbs, 2001). As they become more familiar with the interaction, they come to require less scaffolding, hence the lowered reliance on their prepared notes. Perhaps due to the rapid, iterative nature of the RCs, learners are able to consciously notice these changes, leading to the belief change.

\section{Do RCs Lead to Increased Feelings of Self-Efficacy?}

With current technology it is not possible to directly measure self-efficacy, so we must rely on indirect measures. Murphey (2003) did this by asking learners how confident they felt, whereas in this research I examined learners' feelings regarding perceived changes in their oral competence. Although both the oral performance and peer interaction codes indicate some feelings of learning happening, the $\mathrm{L} 2$ oral competence data provide a more direct line of evidence. In his interview, Riki stated that he believed RCs to be more effective for improving his oral competence than regular conversation activities; Ryuichi was even able to recall specific examples of phrases that he had become competent in using through his RCs.

The survey data was supportive of the interviewees' claims: the majority of respondents indicated that they felt able to speak faster, use more vocabulary, and share their ideas more effectively due to the RCs (see Figure 3). Based on these results, it seems clear that the learners perceived an increase in their oral fluency, concurrent with increased acquisition and/or usage of new vocabulary items. If the learners' beliefs match reality, then the RCs had a potent effect on learners' $\mathrm{L} 2$ oral competence. Furthermore, the fact that learners responded so positively in both the interviews and surveys shows that RCs may be a useful tool for aiding learners in the act of noticing improvements in their L2 competence or at least feeling that they are becoming more competent. This could prove to be valuable to educators who believe in the power of assessment-aslearning (Shohamy, 2005); RCs provide a platform for learners to begin examining their $\mathrm{L} 2$ competence and guiding their own learning, with help from their teachers. 


\section{Conclusion}

In this case study, I sought to examine the role of RCs in learners' belief development. Based on the results of this research, three key areas of beliefs were altered through experiences within RCs. These areas were (a) peer interaction, (b) competence, and (c) self-efficacy. An advantage of RCs is the opportunities they provide for learners to reexperience conversations with multiple peers. This seems to give learners many chances to learn from each other, leading to their seeing $\mathrm{L} 2$ peer conversations as beneficial to learning. By experiencing several iterations of RCs, learners may be able to reflect upon their performance then make conscious adjustments in subsequent conversations. This perceived learning led to feelings of increased self-efficacy regarding their ability to interact in the L2. This implies that RCs could be beneficial for the Japanese public education environment, in which native speakers are in relatively short supply. Through the use of recursive activities, educators can help learners to increase their L2 awareness and to feel more positive about themselves and their learning.

\section{Limitations}

Due to the exploratory nature of this study and the limitations of the case study format, there are several issues to address. First, this research was conducted within a single faculty, at a single Japanese university. For this reason, one must be cautious in generalizing the results to the wider population (Dörnyei, 2007). Furthermore, inferential statistics were not used in this study because of the nonrandom sampling procedure (Brown, 2016). Secondly, learners' beliefs do not always match reality (Wesely, 2012), meaning that their claims need to be compared with performance data from the RCs. A performance analysis could be conducted qualitatively by examining instances of learners picking up and reusing the linguistic expressions of their peers or adjusting their output based on feedback from tutors. A quantitative performance analysis looking at fluency, complexity, and accuracy similar to that conducted by Larsen-Freeman (2006) would make it possible to examine learners' claims regarding changes in oral performance. Finally, this comparison of the performance and beliefs data might shed more light on the apparent links between RCs and learner self-efficacy.

\section{Bio Data}

D. S. Bowyer has been teaching English in Japan for the past 9 years and currently lectures at Nagoya Gakuin University. His research interests include assessment, fluency, interactional competence, and schema theory. <scottybowyer1@gmail.com>

\section{References}

Amrein, J., Bogedin, C., Bowyer, D. S., Deadman, A., Harris, R. B., Koga, A., .. Walters, J. R. (2017). Power-up dialogue 1. Nagoya, Japan: Nagoya University of Foreign Studies Press.

Barcelos, A. M. F. (2006). Researching beliefs about SLA: a critical review. In P. Kalaja \& A. M. F. Barcelos (Eds.), Beliefs about SLA: New research approaches (pp. 7-33). New York, NY: Springer.

Brown, H. D. (2014). Principles of language learning and teaching. White Plains, NY: Pearson Education.

Brown, J. D. (2016). Statistics corner: Questions and answers about language testing statistics. Tokyo: JALT Testing and Evaluation Special Interest Group.

Canale, M., \& Swain, M. (1980). Theoretical bases of communicative approaches to second language teaching and testing. Applied Linguistics, 1, 1-47. https://doi.org/10.1093/applin/l.1.1

Creswell, J. W., Plano Clark, V. L., Gutman, M. L., \& Hanson, W. E. (2003). Advanced mixed methods research designs. In A. Tashakkori \& C. Teddlie (Eds.), Handbook of mixed methods in social \& behavioral research. Thousand Oaks, CA: Sage.

Dörnyei, Z. (2007). Research methods in applied linguistics. Oxford, England: Oxford University Press.

Ellis, R. (2008). The study of second language acquisition (2nd ed.). Oxford, England: Oxford University Press.

Kindt, D. (2004). A systemic view of emergent course design: A multimethod exploration of the complex, dynamic nature of student engagement in an emergent EFL course (Unpublished doctoral dissertation). University of Birmingham, Birmingham, England.

Kindt, D. (2005). A complex systems view of course design: A case study in the application and development of recursive procedures. Nagoya University of Foreign Studies Journal of the School of Contemporary International Studies, 1, 157-191.

Kindt, D., \& Bowyer, D. S. (2018). A working paper exploring the effects of recursive conversations on participants' fluency development in a first-year EFL oral communication course. Nagoya University of Foreign Studies Ronshu, 2, 103-129.

Larsen-Freeman, D. (2006). The emergence of complexity, fluency, and accuracy in the oral and written production of five Chinese learners of English. Applied Linguistics, 27, 590-619. https:// doi.org/10.1093/applin/aml029

Murphey, T. (2001). Tools of recursion, intermental ZPDs \& critical collaborative autonomy. JALT Journal, 23(1), 130-150. Retrieved from http://jalt-publications.org/sites/default/files/pdf-article/ jj-23.1-art7.pdf

Murphey, T. (2003). JFL and EFL videoing student conversations. In M. Swanson \& K. Hill, JALT2002 conference proceedings (pp. 50-53). Tokyo: JALT. Retrieved from http://jalt-publications. org/archive/proceedings/2002/050.pdf 
Nguyen, T., \& Sato, K. (2016). Changes in learner beliefs of Japanese EFL students: An impact of the cooperative strategy learning program. International Journal of English Language Teaching, 4 46-66

O'Connor, J., \& McDermott, I. (1997). The art of system thinking: Essential skills for creativity and problem solving. San Francisco, CA: Thorsons.

Oliver, R., \& Philp, J. (2014). Focus on oral interaction (1st ed.). Oxford, England: Oxford University Press.

Sato, K. (2005). Group dynamics and the impact of strategy instruction on learner beliefs. Paper presented at the 2005 Second Language Research Forum, Columbia University, New York, NY.

Shohamy, E. (2005). The power of tests over teachers: The power of teachers over tests. In D. Tedick (Ed.), Second language teacher education: International perspectives (pp. 101-111). New York, NY: Routledge.

Stubbs, M. (2001). On inference theories and code theories: Corpus evidence for semantic schemas. Interdisciplinary Journal for the Study of Discourse, 21, 437-465. https://doi.org/10.1515/ text.2001.007

Wesely, P. M. (2012). Learner attitudes, perceptions, and beliefs in language learning. Foreign Language Annals, 45, 98-117. https://doi.org/10.1111/j.1944-9720.2012.01181.x

Young, R. F. (2011). Interactional competence in language learning, teaching, and testing. In E. Hinkel (Ed.), Handbook of research in second language teaching and learning (vol. 2, pp. 426-443). New York, NY: Routledge.

\section{Appendix A}

Lesson Procedure

\begin{tabular}{lc}
\hline Activity & Time (min.) \\
\hline 1. Homework check and goal sharing & 3 \\
2. Communication skill practice & 10 \\
3. Conversation 1 & 7 \\
4. Informal tutor feedback & 1 \\
5. Change groups & 2 \\
6. Conversation 2 & 7 \\
7. Tutor feedback & 3 \\
8. Change groups & 2 \\
9. Conversation 3 & 7 \\
10. Feedback and homework setting & 3 \\
\hline
\end{tabular}

1. Check Ss homework and have them share their self-chosen lesson goals as a group.

2. Introduce today's topic and conversation skill. Conduct a short skill-focused activity from the POWER-UP DIALOGUE 1 textbook.

3. Have Ss engage in a 7-minute, three-person group conversation, using their prepared notes. Listen and make notes on any important feedback areas.

4. Provide short informal feedback if required.

5. Two Ss leave the group, and two Ss join.

6. On the same topic as 3, have Ss engage in a 7-minute, three-person group conversation, using their prepared notes. Complete rubric (see Appendix C) while listening to conversation.

7. Provide feedback to Ss based on the feedback rubric. Ensure Ss take notes.

8. Two Ss leave, two arrive.

9. Again on the same topic, have Ss engage in a 7-minute, three-person group conversation, using their prepared notes.

10. Provide feedback to Ss once more and have them make notes. Explain the homework preparation for next week's lesson. 
Appendix B

Example Textbook Lesson

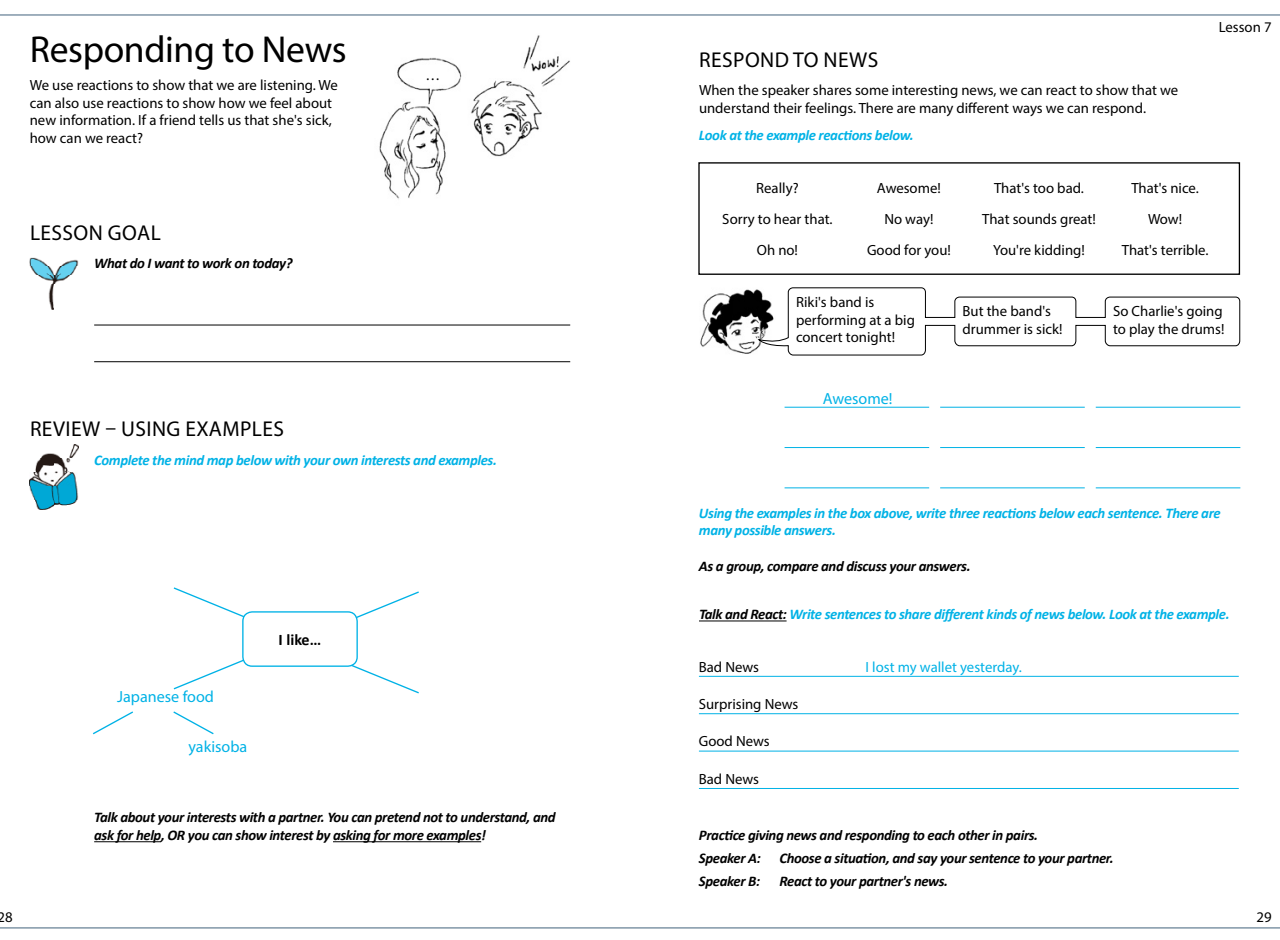

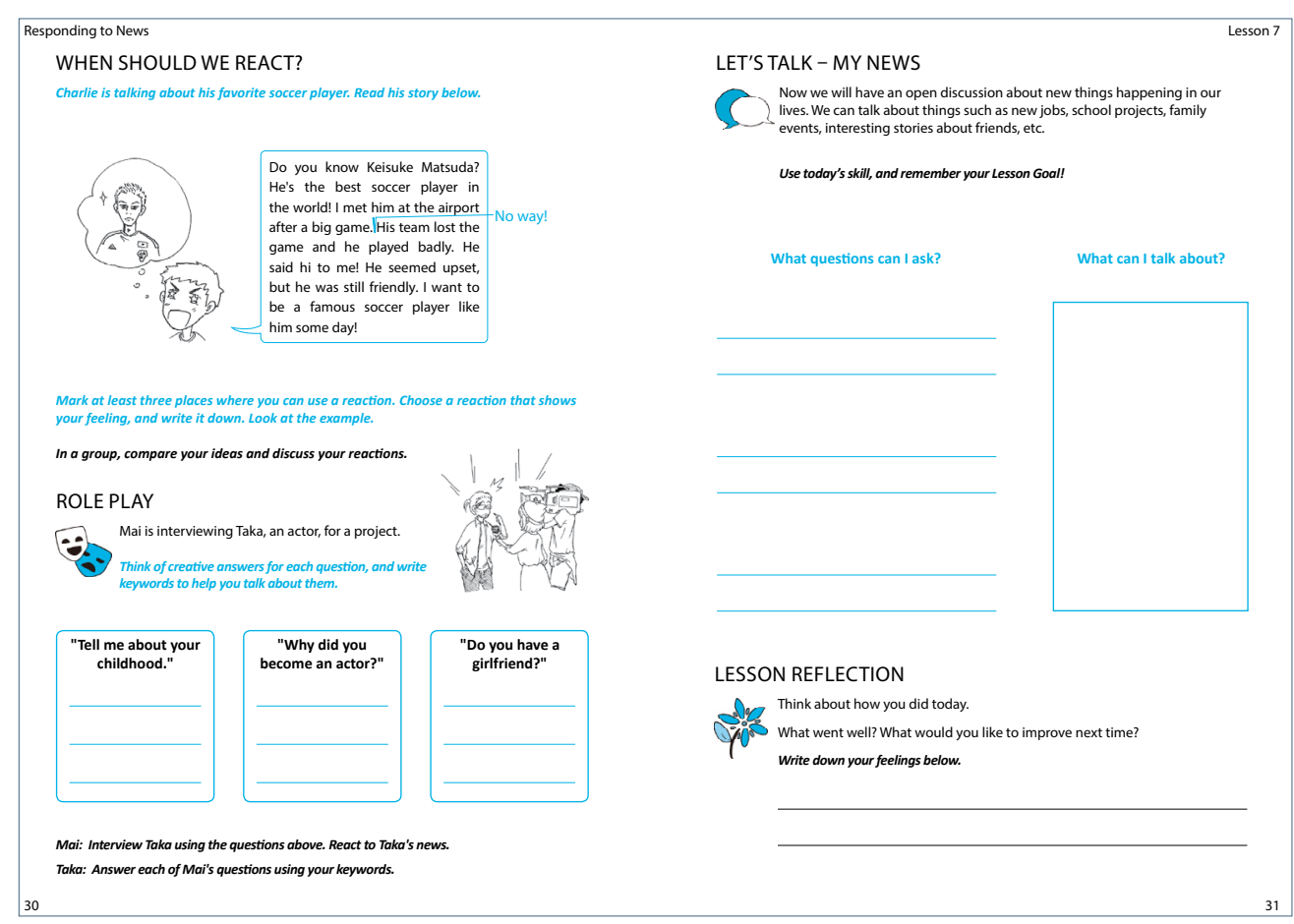




\section{Appendix C}

\section{Feedback Rubric}

\begin{tabular}{|l|l|l|}
\hline Tutor: & Group: & Topic \\
\hline
\end{tabular}

\begin{tabular}{|c|c|c|c|c|c|}
\hline & 1 & 2 & 3 & Score & Notes \\
\hline Content & $\begin{array}{l}\text { Rarely provides detail } \\
\text { when speaking. } \\
\text { Description }\end{array}$ & $\begin{array}{l}\text { Sometimes provides } \\
\text { detail when speaking. } \\
\text { Description, preference }\end{array}$ & $\begin{array}{l}\text { Usually provides rich } \\
\text { information } \\
\text { Description, preference, } \\
\text { reason }\end{array}$ & & \\
\hline Participation & $\begin{array}{l}\text { Only participates when } \\
\text { asked a question; is } \\
\text { often disengaged }\end{array}$ & $\begin{array}{l}\text { Sometimes participates } \\
\text { without being asked } \\
\text { a question; is usually } \\
\text { engaged }\end{array}$ & $\begin{array}{l}\text { Interacts/Asks and } \\
\text { answers questions for a } \\
\text { balanned conversation; } \\
\text { is usually engaged }\end{array}$ & & \\
\hline Understandability & $\begin{array}{l}\text { Rarely attempts to } \\
\text { understand or be } \\
\text { understood }\end{array}$ & $\begin{array}{l}\text { Sometimes attempts } \\
\text { to understand or be } \\
\text { understood, but may } \\
\text { rely on L1 }\end{array}$ & $\begin{array}{l}\text { Usually attempts to } \\
\text { understand or be } \\
\text { understood without } \\
\text { relying on L1 }\end{array}$ & & \\
\hline & & & \multicolumn{2}{|l|}{ Total Score: } & \\
\hline
\end{tabular}

\section{Appendix D}

Semistructured Interview Questions

NOTE: Interviews conducted in Japanese and English

1. How are you doing?

2. How is _____ life? $(* 1)$

3. How about______ ? $(* 2)$

4. What is your image of a good conversation?

a. Where does it come from?

5. How do you know when you've had a good conversation?

6. What do you do after you receive feedback from the teacher?

7. What do you think about changing partners and then continuing the topic?

8. Do you notice any changes in your speech between the conversations?

9. Do you think that your conversational ability has improved during this semester? a. How can you tell?
10. Is there anything else that you want to talk about?

*1: University name. Omitted to protect anonymity.

*2: Course name. Omitted to protect anonymity.

\section{Appendix $\mathrm{E}$}

Survey 1 and 2 RCs Questions

NOTE: Actual surveys administered in Japanese. Unused data not included.

\begin{tabular}{|l|l|l|l|l|}
\hline 35. Feedback from the teacher and my lesson goal are not connected & -2 & -1 & 1 & 2 \\
\hline 36. My English conYersational ability has improved over this semester & -2 & -1 & 1 & 2 \\
\hline 37. My current conversational abiity is the same as at the beginning of the semester & -2 & -1 & 1 & 2 \\
\hline
\end{tabular}

\section{Section C. Classroom Conversations}

I'd like to know about your experiences and your opinions regarding your conversations in PUT classes. Please place check in the appropriate box for each conversation:

\begin{tabular}{|l|l|c|c|}
\hline & I can hardly communicate in English & $\begin{array}{c}\text { I can communicate in English using } \\
\text { my notes }\end{array}$ & $\begin{array}{c}\text { I can communicate in English without } \\
\text { using my notes }\end{array}$ \\
\hline 38. Conversation 1 & & & \\
\hline 39. Conversation 2 & & & \\
\hline 40. Conversation 3 & & & \\
\hline
\end{tabular}

Please circle the number that best fits your feelings:

\begin{tabular}{|l|c|c|c|c|}
\hline & $\begin{array}{c}\text { Completely } \\
\text { disagree }\end{array}$ & $\begin{array}{c}\text { Somewhat } \\
\text { disagree }\end{array}$ & $\begin{array}{c}\text { Somewat } \\
\text { agree }\end{array}$ & $\begin{array}{c}\text { Completely } \\
\text { agree }\end{array}$ \\
\hline 41. I feel most relaxed during conversation 3 & -2 & -1 & 1 & 2 \\
\hline 42. It's tun to speak with new partners about the same topic & -2 & -1 & 1 & 2 \\
\hline 43. Three conversations about the same topic helps me to share my ideas better & -2 & -1 & 1 & 2 \\
\hline 44. I speak the most in conversation 3 & -2 & -1 & 1 & 2 \\
\hline 45. I cannot have a conversation in English for 7 minutes & -2 & -1 & 1 & 2 \\
\hline 46. I fee most nervous during conversation I & -2 & -1 & 1 & 2 \\
\hline 47. I can have a conversation for 7 minutes using only English & -2 & -1 & 1 & 2 \\
\hline 48. Three conversations about the same topic helps me to use new vocabulary & -2 & -1 & 1 & 2 \\
\hline 49. Conversation 3 is more enjoyable than 1 and 2 & -2 & -1 & 1 & 2 \\
\hline 50. All three conversatioos are equally enjoyable & -2 & -1 & 1 & 2 \\
\hline 51. Three conversations about the same topic helps me to improve my speaking speed & -2 & -1 & 1 & 2 \\
\hline 52. I speak the least in conversation 1 & -2 & -1 & 1 & 2 \\
\hline 53. I can speak for 7 minutes using mostly English & -2 & -1 & 1 & 2 \\
\hline
\end{tabular}

54. Final comments: 


\section{Nw

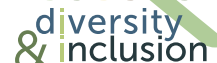 \\ \#jalt2018}

\section{Classroom Conversations}

Please circle the number that best fits your feelings:

\begin{tabular}{|l|c|c|c|c|}
\cline { 2 - 5 } \multicolumn{1}{l|}{} & $\begin{array}{c}\text { Completely } \\
\text { disagree }\end{array}$ & $\begin{array}{c}\text { Somewhat } \\
\text { disagree }\end{array}$ & $\begin{array}{c}\text { Somewat } \\
\text { agree }\end{array}$ & $\begin{array}{c}\text { Completely } \\
\text { agree }\end{array}$ \\
\hline 1. l learned new phrases from my partners & -2 & -1 & 1 & 2 \\
\hline 2. l leaned how to use conversation skills by copying my partners & -2 & -1 & 1 & 2 \\
\hline 3. l learned new vocabulary from my partners & -2 & -1 & 1 & 2 \\
\hline $\begin{array}{l}\text { 4. I can become better at talking in English by having English conversations with other } \\
\text { students }\end{array}$ & -2 & -1 & 1 & 2 \\
\hline $\begin{array}{l}\text { 5. PUT classes have made me believe that I can improve my English speaking ability by } \\
\text { talk with other students }\end{array}$ & -2 & -1 & 1 & 2 \\
\hline 6. PUT classes helped me to become more confident in my Englishspeaking ability & -2 & -1 & 1 & 2 \\
\hline
\end{tabular}

Bowyer: Exploring the Effects of Recursive Conversations on L2 Learner Beliefs

JAPAN ASSOCIATION FOR LANGUAGE TEACHING • JALT2018 » Diversity and Inclusion

\section{Appendix F}

Summary Data for Figures 1-3

Figure 1:

\begin{tabular}{|l|c|c|c|}
\cline { 2 - 4 } \multicolumn{1}{c|}{} & C1 & C2 & C3 \\
\hline I can hardly communicate in English & 0 & 0 & 0 \\
\hline I can communicate in English using my notes & 22 & 11 & 6 \\
\hline I can communicate in English without using my notes & 18 & 29 & 32 \\
\hline
\end{tabular}

Figure 2:

\begin{tabular}{|l|c|c|c|}
\cline { 2 - 4 } \multicolumn{1}{c|}{} & C1 & C2 & C3 \\
\hline Completely disagree & 1 & 0 & 0 \\
\hline Somewhat disagree & 1 & 0 & 4 \\
\hline Somewhat agree & 24 & 25 & 17 \\
\hline Completely agree & 13 & 14 & 18 \\
\hline
\end{tabular}

\section{Figure 3:}

\begin{tabular}{|l|c|c|c|}
\cline { 2 - 4 } \multicolumn{1}{c|}{} & $\begin{array}{c}\text { Three conversations about the } \\
\text { same topic helps me to share my } \\
\text { ideas better }\end{array}$ & $\begin{array}{c}\text { Three conversations about the } \\
\text { same topic helps me to use new } \\
\text { vocabulary }\end{array}$ & $\begin{array}{c}\text { Three conversations about the } \\
\text { same topic helps me to imp imove } \\
\text { my speaking speed }\end{array}$ \\
\hline Completely disagree & 0 & 1 & 0 \\
\hline Somewhat disagree & 3 & 6 & 4 \\
\hline Somewhat agree & 7 & 23 & 20 \\
\hline Completely agree & 30 & 10 & 16 \\
\hline
\end{tabular}

Completely agree

\section{.}

